\title{
Technological differences between açai and juçara pulps and their sorbets
}

\author{
Diferenças tecnológicas entre polpas de açaí e juçara e seus sorbets
}

\section{Ana Paula Silva Siqueira1*, Kyany Ferreira dos Santos', Thaís Alves Barbosa', Lucas de Alvarenga Santos Freire', Yorran Araújo Camêlo'}

1 Instituto Federal Goiano, Department of Food Technology, Campus Morrinhos, Morrinhos/GO - Brazil

\section{${ }^{*}$ Corresponding Author}

Ana Paula Silva Siqueira, Instituto Federal Goiano, Department of Food Technology, Rodovia BR153, km 633, Zona Rural, CEP: 75650-000, Morrinhos/GO - Brazil, e-mail: siqueiracta@gmail.com

Cite as: Technological differences between açai and juçara pulps and their sorbets. Braz. J. Food Technol., v. 21, e2017047, 2018.

Received: Apr. 6, 2017; Accepted: Aug. 14, 2017

\section{Abstract}

Açai and juçara are palm trees that produce similar fruits. However, only the sale of açai is growing on the market for pulps and processed products for human consumption. The aim of this study was to compare açai and juçara pulps from the chemical, bioactive, rheological and technological points of view. Sorbets were elaborated with the pulps and evaluations were carried out regarding the antioxidant activity, polyphenols, anthocyanins, $\mathrm{pH}$, acidity, soluble solids, ratio and colour. The pulps were evaluated rheologically and the sorbets for melting time. Juçara showed better results regarding the bioactive parameters (antioxidants $\approx 151 \mathrm{uM}$ ferrous sulphate/ $\mathrm{g}$ and anthocyanins $\approx 77 \mathrm{mg} .100 \mathrm{~g}^{-1}$ ) and presented a more intense colour (Chroma 17). The pulps were physicochemically similar. The sorbet preserved much of the nutrients and presented a very intense colour, mainly in the juçara sorbet.

Keywords: Euterpe oleracea; Euterpe edulis; Antioxidants; Sorbet.

\section{Resumo}

Açaí e juçara são palmeiras que produzem frutos semelhantes. Contudo, apenas o Açaí está crescendo no mercado de polpas e produtos processados para consumo humano. O objetivo deste estudo foi comparar as polpas de açaí e juçara do ponto de vista químico, bioativo, reológico e tecnológico. Elaboraram-se sorbets com as polpas desses frutos e foram realizadas avaliações dos seguintes parâmetros: atividade antioxidante, polifenóis, antocianinas, pH, acidez, sólidos solúveis, ratio e cor. As polpas foram avaliadas reologicamente e os sorbets foram avaliados quanto ao tempo de fusão. A juçara mostrou melhores resultados quanto aos parâmetros bioativos (antioxidantes $\approx 151 \mu \mathrm{M}$ sulfato ferroso/g e antocianinas $\approx 77 \mathrm{mg}^{1} 100 \mathrm{~g}^{-1}$ ) e apresentou cor mais intensa (Chroma 17). As polpas são físico-quimicamente semelhantes. Os sorbets preservaram grande parte dos nutrientes e apresentaram uma cor muito intensa, principalmente no sorbet de juçara.

Palavras-chave: Euterpe oleracea; Euterpe edulis; Antioxidantes; Sorbet.

\section{Introduction}

The açai (Euterpe oleracea Mart.) and juçara (Euterpe edulis) palms are from different regions of Brazil and their cultivation can last up to 8 years (CARDOSO; LEITE, 2009). According to these authors, the heart of palm is the only product of commercial interest extracted from these plants and is therefore subjected to accelerated and illegal exploitation without the use of adequate management, contributing to the fact that these plants are the most exploited species in the Atlantic Forest.
Açai is a typical fruit of the Amazon region and is mainly produced in the states of Pará and Amazonas (NOGUEIRA et al., 2005). Besides its nutritional value, the motivation for consuming açai incorporates cultural issues and aspects of aesthetics and health, due to the elements that make it a functional food, such as fibre, vitamins and anthocyanins (BOBBIO et al., 2000; SILVA et al., 2006; TEIXEIRA et al., 2008). The juçara palm is more prevalent on the north coast of Rio Grande do Sul, Brazil, and its fruit is popularly known as "the açai of the 
Atlantic Forest". This fruit is considered energetic and contains vitamin A, iron, water, anthocyanins, and phenolic compounds (SANTOS et al., 2008).

The juçara and açai fruits are physically similar. They are globose, violaceous to vinous black, size of 1 to $3 \mathrm{~cm}$ in diameter and are the raw material for the production of pulp or juice (BORGES et al., 2015). Their pulps are highly perishable and this condition can be aggravated due to the exposure to microbial agents depending on the post-harvest practices. Despite its wide distribution in Brazil, the juçara fruits are much less consumed than açai fruits. In recent years, acai pulp has been commercialized by supermarkets, gyms and fast food stores, involving consumers with high purchasing power (BRITO et al., 2007; SANTANA; GOMES, 2005; SANTANA et al., 2007).

The aim of this study was to compare the açai and juçara pulps, and the sorbets elaborated from the pulps of these fruits, from the chemical, bioactive, rheological and technological points of view.

\section{Materials and methods}

The pulps were obtained from local markets (açai from Para and juçara from São Paulo). They were transported under refrigeration to carry out the evaluations. The sorbets were elaborated from the pulps using additional ingredients such as brown sugar, lemon juice, banana and soy milk in the proportions shown in Table 1.

To formulate the sorbets, the frozen açai and juçara pulps were mixed with the banana pulp, brown sugar and soy milk. The lemon juice was the last ingredient to be added and contributed to the viscosity of the product. The mixture was frozen, matured for 20 hours and then further homogenized to obtain the sorbet.

$100 \mathrm{~g}$ of sorbet were placed in a sieve over a container for the melting analysis. As the sample melted through the sieve, the liquid was retained in the container. Every thirty minutes the melted sorbet was weighed using a semi-analytical balance. This analysis was carried out in triplicate and continued until the complete melting of the product.

The colours of the pulps and sorbets were determined from the three parameters defined by the CIELAB system. The parameters $L^{*}, a^{*}$ and $b^{*}$ were measured using the colorimeter (Hunterlab, ColorQuest II), where $L^{*}$ defines the luminosity $\left(L^{*}=0\right.$ black and $L^{*}=100$ white); and

Table 1. Formulation of the açaí and juçara sorbets.

\begin{tabular}{|ccc|}
\hline Ingredients & Açai sorbet \% & Juçara sorbet \% \\
\hline Fruit Pulp & 75 & 75 \\
Banana Pulp & 15 & 15 \\
Brown sugar & 4 & 4 \\
Soy milk & 4 & 4 \\
Lemon juice & 2 & 2 \\
\hline
\end{tabular}

$a^{*}$ and $b^{*}$ define the chromaticity $\left(+a^{*}\right.$ red and $-a^{*}$ green, $+b^{\star}$ yellow and $-b^{*}$ blue) (HUNTERLAB, 1996). With these values, the Hue angle and the colour intensity (Chroma) were calculated.

The total soluble solids content was determined from the Brix readings at $20^{\circ} \mathrm{C}$ in a digital refractometer (Atago $\mathrm{N}$-1E). The $\mathrm{pH}$ was measured using a digital potentiometer ( $\mathrm{pH}$ Meter HI-9224), and the total titratable acidity by titration with $0.1 \mathrm{~N}$ sodium hydroxide $(\mathrm{NaOH})$ (HORWITZ, 2010).

The phenolic compound contents in the ethanolic extracts were determined in a spectrophotometer (Biospectro SP-220), at $750 \mathrm{~nm}$ using the Folin-Ciocalteau reagent according to Waterhouse (WATERHOUSE, 2002). The results were expressed in milligrams of gallic acid equivalent (GAE) per 100 grams of sample. The antioxidant capacity was determined from the ferric reducing antioxidant power (FRAP). The anthocyanins were determined using the method proposed by Francis in an ethanol-HCl extract and the readings made using a spectrophotometer at 535 nm (FRANCIS, 1982)

The rheological behaviour of the pulps was also determined, using a rotational rheometer of concentric cylinders (Searle- type, Brookfield), model R/S plus SST 2000. The measurements were carried out at $10,20,30,40,50,60,70$ and $80^{\circ} \mathrm{C}$, the temperature being adjusted in a thermostatic bath. The equipment provided data for the shear force and deformation rate.

\section{Results and discussion}

Regarding the bioactive composition of the açai and juçara pulps, the juçara pulp showed a higher antioxidant capacity and anthocyanin content than the açaí pulp, but they did not differ in their polyphenol compound contents, which were expressive (Table 2). In studies on the functional benefits of these fruits, it can be affirmed that the intense purple coloration of both products was due to the presence of anthocyanins, and that the antioxidant capacity, also proven in this study, was almost totally attributable to these pigments (OLIVEIRA et al., 2015).

Anthocyanins are responsible for the blue, red and violet colours of most fruits. The high anthocyanin levels in both pulps, higher in the juçara pulp, lead to the expectation that this pulp would have a more intense colour than açai pulp, which was confirmed by the data on luminosity and chromaticity obtained in the present study (Table 2). The luminosity value of the Açaí pulp was greater than that of the juçara pulp, and the chromaticity values, with positive values of $a^{*}(>0)$, indicated that both pulps were red. However, it can also be seen from the values of the Hue angles and colour saturation that the juçara pulp was red vinous black. 
Table 2. Antioxidants, polyphenols, anthocyanins, $\mathrm{pH}$, titratable acidity and soluble solids, luminosity, hue and chroma of the juçara and açai pulps.

\begin{tabular}{|c|c|c|}
\hline \multicolumn{3}{|c|}{ Chemical and bioactive composition (mean values \pm SD, $n=3$ ) } \\
\hline Bioactive composition & Juçara pulp & Açai pulp \\
\hline Antioxidants ( $\mu \mathrm{M}$ ferrous sulphate/g) & $150.91^{a} \pm 4.83$ & $62.21^{b} \pm 1.04$ \\
\hline Polyphenols (mg/100 g) & $46.25^{a} \pm 3.32$ & $47.55^{\mathrm{a}} \pm 3.43$ \\
\hline Anthocyanins (mg/100 g) & $76.85^{a} \pm 0.74$ & $34.91^{b} \pm 3.62$ \\
\hline \multicolumn{3}{|l|}{ Chemical composition } \\
\hline $\mathrm{pH}$ & $5.25^{\mathrm{a}} \pm 0.03$ & $5.16^{a} \pm 0.01$ \\
\hline Titratable acidity (g/100 g) & $0.25^{\mathrm{a}} \pm 0.02$ & $0.19^{a} \pm 0.01$ \\
\hline Soluble solids ( ${ }^{\circ}$ Brix) & $5.53^{a} \pm 0.30$ & $4.50^{\mathrm{a}} \pm 0.10$ \\
\hline Ratio & $22.12^{a} \pm 0.03$ & $23.68^{a} \pm 0.10$ \\
\hline \multicolumn{3}{|l|}{ Colour } \\
\hline Luminosity & $1.56^{b} \pm 0.20$ & $9.50^{a} \pm 0.28$ \\
\hline Hue & $17.22^{b} \pm 0.35$ & $35.95^{\mathrm{a}} \pm 1.87$ \\
\hline Chroma & $17.39^{a} \pm 0.99$ & $9.09^{b} \pm 0.21$ \\
\hline
\end{tabular}

a,bThe same letters in the same line do not differ significantly from each other according to Tukey's test at $5 \%$ probability. Captions: SD = Standard deviation; $\mathrm{n}=$ number of replications.

The importance of determining compounds with antioxidant activity and the total antioxidant capacity of foods is due the fact that human cells depend on a certain antioxidant capacity to provide protection against the harmful effects of radicals and reactive oxygen species, which are inevitable consequences of aerobic life. The respiratory process and other oxidative reactions lead to the formation of radicals, which cause damage to the body and contribute to many diseases, such as: inflammation, malignant tumours, Alzheimer's disease and cardiovascular diseases, and may accelerate the aging process (SILVA et al., 2010).

Studying phenolic compounds is also interesting because these compounds are multifunctional as antioxidants, acting in several ways, combating radicals, interrupting their propagation, blocking the action of specific enzymes and modifying the redox potential of the medium. Polyphenol compounds are also the most abundant antioxidants in the diet. The daily consumption can reach $1 \mathrm{~g}$, which is much higher than the consumption of all the other phytochemicals classified as antioxidants. The main groups of polyphenol compounds are the phenolic acids, such as chlorogenic acid present in coffee; stilbenes, such as resveratrol present in grapes and wine; coumarins, such as the furanocoumarins in celery; lignins, such as the lignans in linseed; and flavonoids, represented in this study by the anthocyanins (MANACH et al., 2004).

Regarding bioactive compounds, the açai and juçara pulps can be compared with other red fruits. Machado et al. (2013) reported the phenolic compound contents in strawberried (107 mg.100 g-1), plums (58 mg.100 g ${ }^{-1}$ ) and blackberries (92 mg.100 $\mathrm{g}^{-1}$ ), and also described the anthocyanin contents in the same

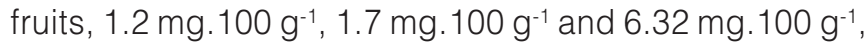
respectively. Silva et al. (2011) reported the anthocyanin levels for four varieties of strawberry (39 mg.100 $\left.\mathrm{g}^{-1}\right)$, eight varieties of blackberry (107 mg.100 g-1) and nine varieties of blueberry (13 mg. $100 \mathrm{~g}^{-1}$ ). Rufino et al. (2010) described the antioxidant activities in 18 non-traditional fruits from Brazil, including açai ( $\left.28 \mu \mathrm{mol} \mathrm{Fe}_{2} \mathrm{SO} 4 / \mathrm{g}\right)$, juçara (85 $\mu \mathrm{mol} \mathrm{Fe} \mathrm{SO}_{2} / \mathrm{g}$ ), Jaboticaba (88 $\mu \mathrm{mol} \mathrm{Fe}_{2} \mathrm{SO} 4 / \mathrm{g}$ ) and Acerola (148 $\mu \mathrm{mol} \mathrm{Fe}_{2} \mathrm{SO} / \mathrm{g}$ ). Castro et al. (2016) evaluated the efficiency of a prior heat treatment of the juçara fruits (E. edulis) used in the processing of pulp destined for the production of a beverage and also found high levels of anthocyanins.

The $\mathrm{pH}$ data are also important for colour, since the anthocyanins present different colours depending on the $\mathrm{pH}$ of the medium. The $\mathrm{pH}$ values of the açaí and juçara pulps did not differ between themselves (Table 2). The $\mathrm{pH}$ of the açaí pulp was in accordance with the limit established by the Quality and Identity Standards of Normative Instruction No. 01 of January $7^{\text {th }}$, which determined a minimum value of 4.0 and maximum of 6.20 (BRASIL, 2000). If the juçara pulp is evaluated by the same standard, it is also within the established limit, but currently there is no legislation to establish standards of identity and quality for juçara. The titratable acidity values were also not significantly different between the samples and within the current legislation, (maximum of $0.40 \mathrm{~g} / 100 \mathrm{~g}$ for acidity).

The total solids concentrations of the products were low (Table 2). According to the standards of identity and quality for açai pulp, the minimum soluble solids content is $8 \%$ (BRASIL, 2000). This variation depends on the way the pulps are produced, due to the addition of water, but can also be justified by the cultivation conditions. Soluble solids, acidity and the ratio are important technological indexes for the production of derived products. They are related to yield, colour and also the taste of the final product, since an ideal balance between acidity and 
sweetness (ratio) is excellent for the commercialization of processed products.

The rheological behaviour of the pulps is important from the technological point of view. From these data it is possible to classify the fluid type and predict the viscosity changes in the pulp at different processing temperatures. They are also of fundamental importance in energy saving, which is becoming increasingly important. This can be seen in the studies of Sousa et al. (2014).

Both açaí and juçara pulps can be classified as non-Newtonian fluids (Figure 1). A fixed deformation rate $\left(250 \mathrm{~s}^{-1}\right)$ was observed, simulating the industrial value that is always greater than $100 \mathrm{~s}^{-1}$, the shear force decreasing with increase in temperature, in both cases. It can also be seen that the apparent viscosity decreased with increase in the rate of deformation, indicating a pseudoplastic behaviour for the pulps, probably due to the presence of asymmetric particles in suspension. At rest they present a disordered state, but when submitted to shear force, the particles or molecules tend to orient in the direction of the applied force. Juçara, which presented higher solids contents, tended to have a higher viscosity at most of the evaluation points. The decrease in apparent viscosity with increase in deformation rate can be explained by structural changes in the sample due to the hydrodynamic forces generated, and the greater alignment of the molecules in the direction of the applied tension (ALPASLAN; HAYTA, 2002). According to Pelegrine and Araújo (2015), the importance of the rheological behaviour is due to its use as a quality measure. Besides, it is indispensable in projects, evaluations and the operation of food processing equipment.

Regarding the antioxidant capacity, the sorbet of juçara showed a higher value than that of açaí. However, both were considerably high for a processed product and the values were consistent with the antioxidant capacity of the fruits (Table 3). A positive correlation between the phenolic compounds, anthocyanins and antioxidant capacity is widely reported in the literature. According to the comparisons made by Rufino et al. (2010) who analysed açaí and juçara pulps, little was lost in the total antioxidant capacity during the processing of the pulps to formulate the sorbets, since they maintained a considerable amount of this capacity and of the antioxidant agents. Thus, the açaí and juçara sorbets are sources of antioxidant agents and can play an important role in consumer health.

Besides contributing with antioxidant activity, the anthocyanins are responsible for the colour of the açaí and juçara sorbets. The main disadvantage of anthocyanins over synthetic dyes is the change in coloration due to chemical reactions in the food products, since anthocyanins have chromophoric groups that are very sensitive to changes in $\mathrm{pH}$ (FOSSEN et al., 1998). In this study, it was observed that the colours of the sorbets were very consistent and red, and that the colour of the juçara sorbet was even more intense, which was also confirmed by the lower luminosity and higher chroma values (Table 2). On the market, these products would have natural pigmentation, dispensing the use of synthetic dyes.

The acidity and $\mathrm{pH}$ values are consistent with the use of lemon juice in the formulations (Table 2). The acidification of processed products has a significant effect on the preservation and chemical stability of the food, correlated with the anthocyanin content. However, a balance between the acidity and soluble solids content is essential to ensure a pleasant taste of the product for the consumer. The açaí and juçara sorbets had similar soluble solids contents, ensuring that the solids of each
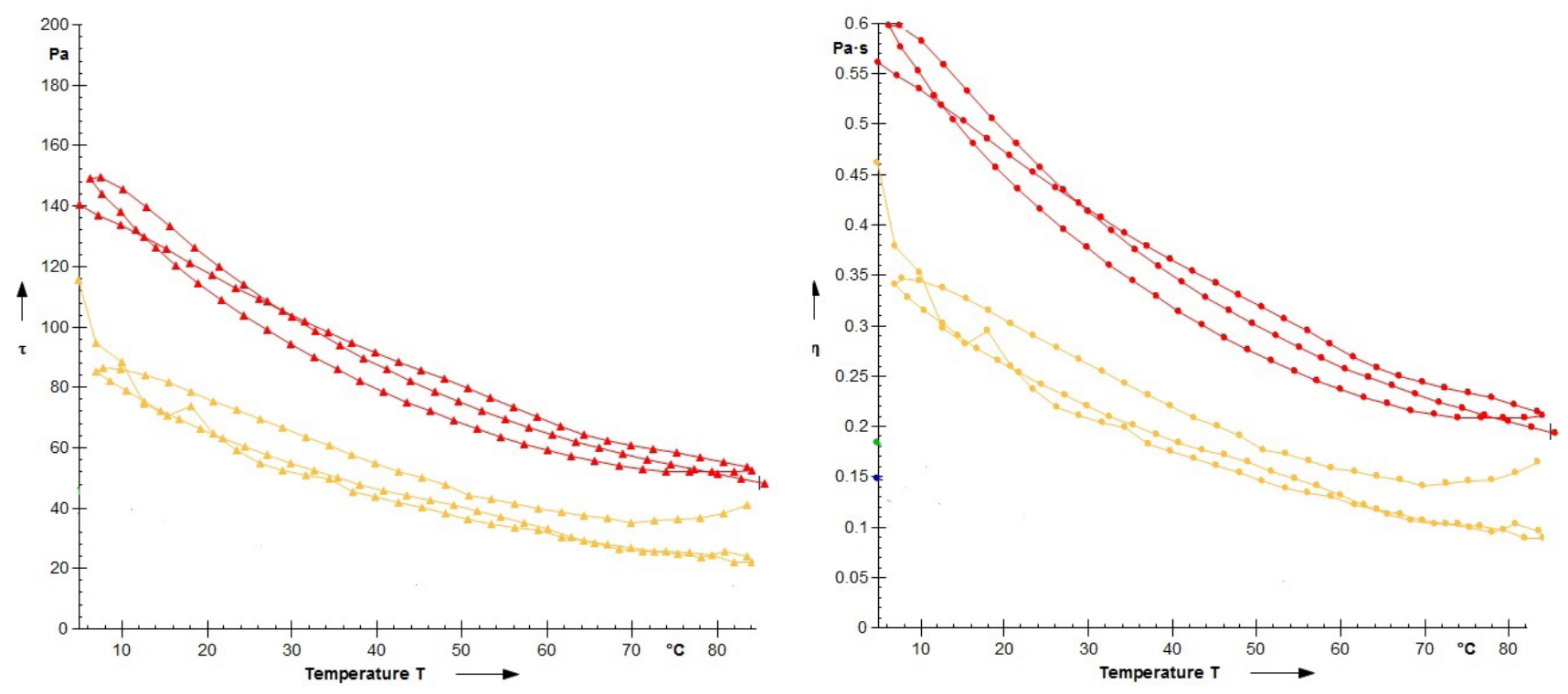

Figure 1. The classification of açaí and juçara. 
Technological differences between açai and juçara pulps and their sorbets

Siqueira, A. P. S. et al.

Table 3. Antioxidants, polyphenolic compounds, anthocyanins, pH, titratable acidity and soluble solids in the juçara and açaí sorbets.

\begin{tabular}{|c|c|c|}
\hline \multicolumn{3}{|c|}{ Chemical and bioactive composition } \\
\hline Bioactive composition & Juçara & Açaí \\
\hline Antioxidants ( $\mu \mathrm{M}$ ferrous sulphate/g) & $87.43^{a} \pm 4.07$ & $30.44^{b} \pm 0.20$ \\
\hline Polyphenols (mg/100 g) & $69.41^{a} \pm 0.17$ & $32.52^{b} \pm 1.32$ \\
\hline Anthocyanins (mg/100 g) & $47.66^{a} \pm 0.47$ & $17.20^{\mathrm{b}} \pm 0.45$ \\
\hline \multicolumn{3}{|l|}{ Chemical composition } \\
\hline $\mathrm{pH}$ & $4.14^{\mathrm{a}} \pm 0.01$ & $3.98^{b} \pm 0.01$ \\
\hline Titratable acidity (g/100 g) & $0.43^{\mathrm{a}} \pm 0.02$ & $0.37^{a} \pm 0.02$ \\
\hline Soluble solids ( ${ }^{\circ}$ Brix) & $10.03^{a} \pm 0.2$ & $10.00^{\mathrm{a}} \pm 0.05$ \\
\hline Ratio & $23.32^{a} \pm 0.11$ & $27.00^{\mathrm{a}} \pm 0.03$ \\
\hline \multicolumn{3}{|l|}{ Colour } \\
\hline Luminosity & $2.54^{b} \pm 0.3$ & $13.17^{a} \pm 0.45$ \\
\hline Hue & $19.61^{b} \pm 0.62$ & $48.42^{a} \pm 2.37$ \\
\hline Chroma & $18.17^{b} \pm 0.35$ & $13.05^{\mathrm{a}} \pm 0.59$ \\
\hline
\end{tabular}

a,b The same letters in the same line do not differ significantly from each other according to Tukey's test at $5 \%$ probability.

individual pulp and sugar content were consistent, allowing for an equal balance between sweetness and acidity for both products. It is important to note that the soluble solids content of $10^{\circ}$ Brix is low in relation to the standard formulations of processed products such as sorbets, nectars and sweets (Table 2).

The graphs show that the juçara sorbet melted faster than the acai sorbet. The consumers prefer sorbets that maintain their original format longer and thus the açai sorbet showed better behaviour.

\section{Conclusions}

The pulps are physicochemically similar. The sorbets preserved much of the nutrients and presented very intense colours, mainly in the case of the juçara sorbet.

\section{References}

ALPASLAN, M.; HAYTA, M. Rheological and sensory properties of pekmez (grape molasses)/tahin(sesame paste) blends. Journal of Food Engineering, v. 54, n. 1, p. 89-93, 2002. http://dx.doi. org/10.1016/S0260-8774(01)00197-2.

BOBBIO, F. O.; DRUZIAN, J. I.; ABRÃO, P. A.; BOBBIO, P. A.; FADELLI, S. Identificação e quantificação das antocianinas do fruto do açaizeiro (Euterpe oleracea Mart.). Ciência e Tecnologia de Alimentos, v. 20, n. 3, p. 388-390, 2000. http://dx.doi. org/10.1590/S0101-20612000000300018.

BORGES, M. G.; CARVALHO, I. C. M.; STEIL, C. A. A. Juçara vai à escola: aprendizagem entre pessoas, coisas e instituições. Horizontes Antropológicos, v. 21, n. 4, p. 309-329, 2015. http:// dx.doi.org/10.1590/S0104-71832015000200013.

BRASIL. Ministério da Agricultura e do Abastecimento. Instrução Normativa $n^{\circ} 1$, de 7 de janeiro de 2000. Aprova o Regulamento Técnico Geral para fixação dos Padrões de Identidade e Qualidade para polpa de fruta. Diário Oficial [da] República Federativa do Brasil, Brasília, DF, 2000. Seção 1, p. 54.
BRITO, E. S.; ARAÚJo, M. C. P.; ALVES, R. E.; CARKEet, C. C.; CLEVIDENCE, B.; NOVOTNY, J. A. Anthocyanins present in selected tropical fruits: acerola, jambolão, Jussara e guarabiju. Journal of Agricultural and Food Chemistry, v. 55, n. 23, p. 9389-9394, 2007. PMid:17929888. http://dx.doi.org/10.1021/ jf0715020.

CARDOSO, L. M.; LEITE, J. P. V. Palmeira Juçara: a exploração dos frutos é mais ecológica e rentável do que a do palmito. Viçosa: Espaço do Produtor, 2009. Accessed on: <https://www2.cead.ufv. br/espacoProdutor/scripts/verArtigo. php?codigo=19\&acao=exibir $>$. Available at: 12 june 2017

CASTRO, R. W.; BORGES, G. S. C.; GONZAGA, L. V.; RIBEIRO, D. H. B. Qualidade do preparado para bebida obtido a partir de polpa de juçara submetida ao tratamento térmico. Brazilian Journal of Food Technology, v. 19, n. e2015008, 2016. http:// dx.doi.org/10.1590/1981-6723.081.

FOSSEN, T.; CABRITA, L.; ANDERSEN, O. M. Colour and stability of pure anthocyanins infuenced by $\mathrm{pH}$ including the alkaline region. Food Chemistry, v. 63, n. 4, p. 435-440, 1998. http:// dx.doi.org/10.1016/S0308-8146(98)00065-X.

FRANCIS, F. J. Analysis of anthocyanins. In: MARKAKIS, P. (Ed.). Anthocyanins as food colors. New York: Academic Press, 1982. v. 1, p. 181-207.

HORWITZ, W. (Ed.). Official methods of analysis of the Association of Official Analytical Chemists. 18th ed. Gaithersburg: AOAC, 2010.

HUNTERLAB. CIE L* $\mathbf{a}^{*} \mathbf{b}^{*}$ color scale. Virginia: HUNTERLAB, 1996. 4 p. (Applications note, v. 8, n. 7).

MACHADO, W. M.; PEREIRA, A. D.; MARCON, M. V. Efeito do processamento e armazenamento em compostos fenólicos presentes em frutas e hortaliças. Agricultural Science and Engineering, v. 19, n. 1, p. 17-30, 2013.

MANACH, C.; SCALBERT, A.; MORAND, C.; RÉMÉSY, C.; JIMÉNEZ, L. Polyphenols: food sources and bioavailability. 
Technological differences between açai and juçara pulps and their sorbets

Siqueira, A. P. S. et al.

American Society for Clinical Nutrition, v. 79, n. 5, p. 727-747, 2004. PMid:15113710.

NOGUEIRA, O. L.; FIGUEIRÊDO, F. J. C.; MULLER, A. A. Açaí. Belém: Embrapa Amazônia Oriental, 2005. 137 p. (Sistemas de Produção, 4).

OLIVEIRA, A. G.; COSTA, M. C. D.; ROCHA, S. M. B. M. Benefícios funcionais do açaí na prevenção de doenças cardiovasculares. Journal of Amazon Health Science, v. 1, n. 1, p. 1-10, 2015.

PELEGRINE, D. H. G.; ARAÚJO, G. logurte de Juçara: formulação e correlação entre os parâmetros reológicos. In: CONGRESSO BRASILEIRO DE ENGENHARIA QUÍMICA - COBEQ, 20., 2014, Florianópolis. Anais... São Paulo: Editora Blucher, 2015. p. 4785-4792. v. 1, n. 2. http://dx.doi.org/10.5151/chemengcobeq2014-1589-18533-173513.

RUFINO, M. S. M.; ALVES, R. E.; BRITO, E. S.; PÉREZ-JIMÉNEZ, J.; SAURA-CALIXTO, F.; MANCINI-FILHO, J. Bioactive compounds and antioxidant capacities of 18 non-traditional tropical fruits from Brazil. Food Chemistry, v. 121, n. 4, p. 996-1002, 2010.

SANTANA, A. C.; GOMES, S. C. Mercado, comercialização e ciclo de vida do mix de produtos do açaí no Estado do Pará. In: CARVALHO, D. F. (Ed.). Ensaios selecionados sobre a economia da Amazônia nos anos 90. Belém: UNAMA, 2005. v. 1 , p. $85-115$.

SANTANA, A. C.; SANTANA, A. L.; NOGUEIRA, A. K. M. Retornos à escala e vantagem competitiva de custo das empresas de polpa de frutas no estado do Pará. Amazônia Ciência \& Desenvolvimento, v. 2, n. 1, p. 187-203, 2007.
SANTOS, G. M.; MAIA, G. A.; SOUSA, P. H.; COSTA, J. M.; FIGUEIREDO, R. W.; PRADO, G. M. Correlação entre atividade antioxidante e compostos bioativos de polpas comerciais de açaí(Euterpe oleracea Mart). Archivos Latinoamericanos de Nutricion, v. 58, n. 2, p. 187-192, 2008. PMid:18833997.

SILVA, I. M.; SANTANA, A. C.; REIS, M. S. Análise dos retornos sociais oriundos de adoção tecnológica na cultura do açaí no Estado do Pará. Amazônia: Ciência e Desenvolvimento, v. 2, n. 3, p. 25-37, 2006.

SILVA, M. L. C.; COSTA, R. S.; SANTANA, A. D. S.; KOBLITZ, M. G. B. Phenolic compounds, carotenoids and antioxidant activity in plant products. Semina: Ciências Agrárias, v. 31, n. 3, p. 669-682, 2010. http://dx.doi.org/10.5433/1679-0359.2010v31n3p669.

SILVA, R. S.; VENDRUSCOLO, J. L.; TORALLES, R. P. Avaliação da capacidade antoxidantes em frutas produzidas na região Sul do RS. Revista Brasileira de Agrociência, v. 17, n. 3-4, p. 392-400, 2011.

SOUSA, E. P.; QUEIROZ, A. J. M.; FIQUEIRÊDO, R. M. F.; LEMOS, D. M. Comportamento reológico e efeito da temperatura da polpa de pequi em diferentes concentrações. Brazilian Journal of Food Technology, v. 17, n. 3, p. 226-235, 2014. http://dx.doi. org/10.1590/1981-6723.1214.

TEIXEIRA, L. N.; STRINGHETA, P. C.; OLIVEIRA, F. A. Comparação de métodos para quantificação de antocianinas. Revista Ceres, v. 55, n. 4, p. 297-304, 2008.

WATERHOUSE, A. L. Polyphenolics: determination of total phenolics. In: WROLSTAD, R. E. Current protocols in food analytical chemistry. New York: John Wiley \& Sons, 2002. 7 p. 